\title{
Image Schema-Based Instruction in English Grammar
}

\author{
Mayu Shintani \\ Tokyo Denki University \\ Kazumasa Mori \\ Bunkyo University
}

Takuya Ohmori

Tama University

\section{Reference Data:}

Shintani, M., Mori, K., \& Ohmori, T. (2016). Image schema-based instruction in English grammar. In P. Clements, A. Krause, \& H. Brown (Eds.), Focus on the learner. Tokyo: JALT.

Cognitive linguistics has been aimed at revealing the very nature of language for the last several decades. One of the field's most significant contributions has been the abstraction of the general patterns, or image schemas, underlying grammatical concepts. In this paper, we propose that English grammar-teaching methods adopting image schema theory offer strong benefits for language teaching. As schematic explanations given to learners are more visible and comprehensible than ordinary verbal-based ones, this method offers a clearer and more engaging way to understand the target grammar. We also present data collected from experiments conducted with more than 400 native Japanese-speaking students at one national and one private university that support the effectiveness of this method.

認知言語学は産声をあげてここ数十年の間, 人間の言語の真の姿を明らかにすることに専心してきた。この学問分野がつ まびらかにしてきた数々の言語現象のうち, 最も有益な成果のひとつにイメージ図式理論の構築があげられる。イメージ図式 とは文法および語彙構造のひな形となるものである。本論文は認知言語学のイメージ図式理論を応用した英文法教材の学 習効果を一国立大学と一私立大学に学ぶ 400 人以上の日本人学部生を対象に行った実験結果をもとに実証的な知見から論 じている。 rammar learning is often seen as the least interesting part of language learning. $\checkmark$ Learners and educators alike may seek alternative or relatively "burden-free" methods to approach grammar. The purpose of this study was to investigate the learning effects of a visual grammar-teaching method based on image schema theory, which has been advanced in cognitive linguistics. In this paper, we begin with an overview of the theoretical framework, followed by a discussion of the applicability of cognitive linguistics to the subject of grammar teaching. We then discuss an experiment that was conducted in 2015 with 424 1st- and 2nd-year Japanese undergraduate students to measure the learning effects of image schema-based explanations of English grammar. The participants were randomly divided into two groups and studied the same three grammar items but with different explanations: one group with image schema-based explanations and the other with conventional verbal-based explanations. Finally, we discuss the experimental results obtained from a pretreatment test and a posttreatment test given to the participants.

Image Schemas as Abstract Conceptual Patterns Cognitive Linguistics and Its Approach to Language

Researchers in cognitive linguistics claim that not only a specific part of the brain, but rather the whole human cognitive system, influences the structure of language. Practitioners of cognitive linguistics thus try to construct a model of the human language system by looking at language and its connections with human sensory and perceptual experience in the world. These researchers (Johnson, 1987, 2005; Lakoff \& Johnson, 1999; Langacker, 2008) have considered the model to be a collection of patterns that provide a rich basis for every language. These abstract patterns, called image schemas, are mental representations merged with everyday sensory and perceptual experiences of physical objects. 


\section{Image Schemas: The Case of the Preposition In}

Humans possess physical bodies and thus have interactive experiences with external physical objects through the mediation of the sensory-perceptual system. Image schemas are patterns that arise from these interactions with physical objects (Evans, 2007, pp. 106-107), which are then generalized to describe nonphysical relationships.

Let us examine the following examples. When we have direct or indirect interactive experiences with objects, such as having a cat in the house, putting some apples in a basket, and arriving in a town, the interactions are all somewhat similar: we have something in or are putting something into something else. With repeated instances of sensory-perceptual experience with containers, we develop an abstract pattern, an inclusive relationship, as shown in Figure 1.

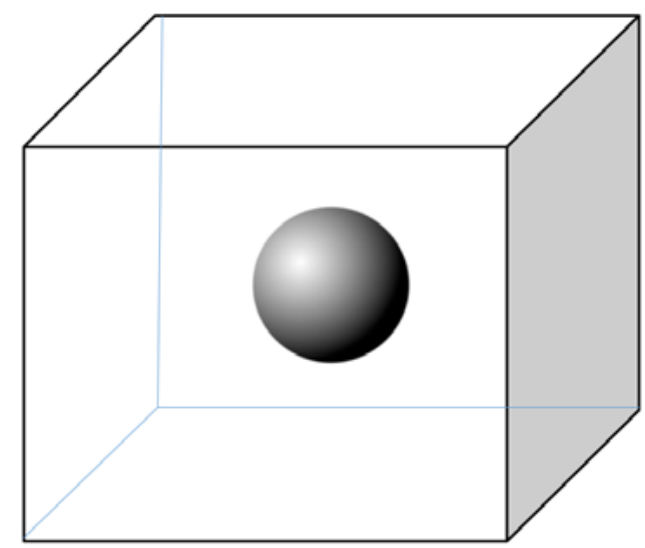

Figure 1. Image schema of an inclusive relationship.

Image schemas provide the basis for the meanings of lexical and grammatical concepts in a language (Johnson, 1987). The inclusive relationship schema in Figure 1 therefore provides the basis for the meaning of the preposition in:

a. My cat is in the house.

b. Put these apples in the basket.

c. They are in love.

d. Everyone was in a good mood.
When using these sentences, English speakers perceive an inclusive relationship between the things. Actually, house and basket are entities with an interior, boundary, and exterior, so that they can hold something inside of them. However, even where there is no boundary or exterior, as in examples $c$ and $d$, this inclusive relationship seems to work, too. Love and mood can also contain things, even though they are intangible, abstract concepts. Most importantly, we subconsciously perceive an inclusive relationship even with such nontangible objects. It seems that we impose an in-out orientation even on nonphysical objects. In the case of examples $c$ and $d$, we conceive of love and mood as substantial entities and see them as containers having an in-out orientation. What is metaphorically mapped between the tangible and nontangible domain is the image schema of an inclusive relationship as seen in Figure 1.

As illustrated in Figure 2, the image schema can be metaphorically mapped from the tangible in onto abstract concepts to provide the basis for abstract thoughts, namely, the nontangible in.

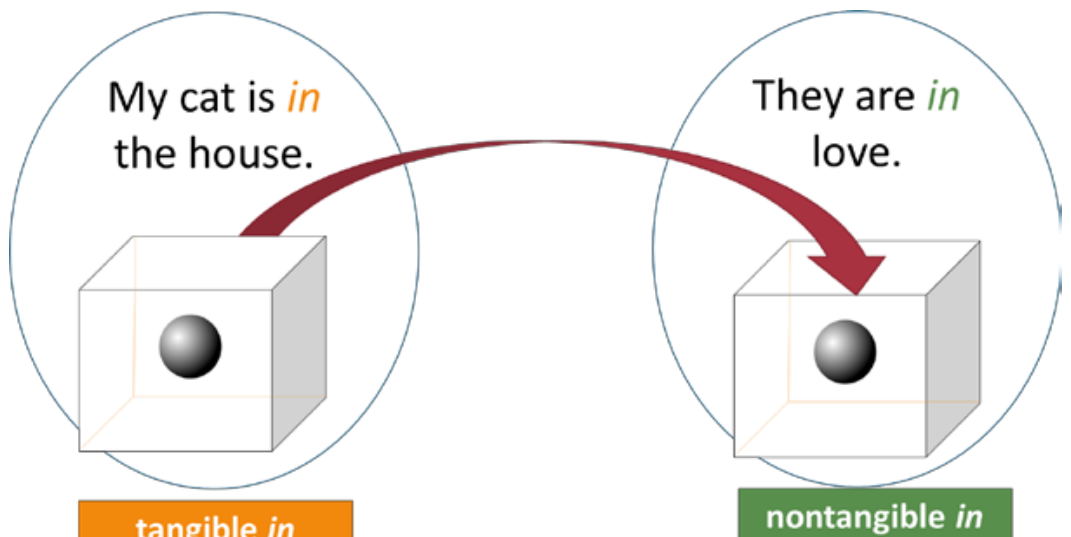

Figure 2. Image schema of the inclusive relationship carried over from tangible in onto nontangible in.

Considering this, it is clear that the image schema serves as the central meaning of in Figure 3 shows the model of the meaning extension of the preposition in in which the inclusive relationship schema serves as a basis for every usage of in.

$$
\text { KFRONT PAGE }
$$




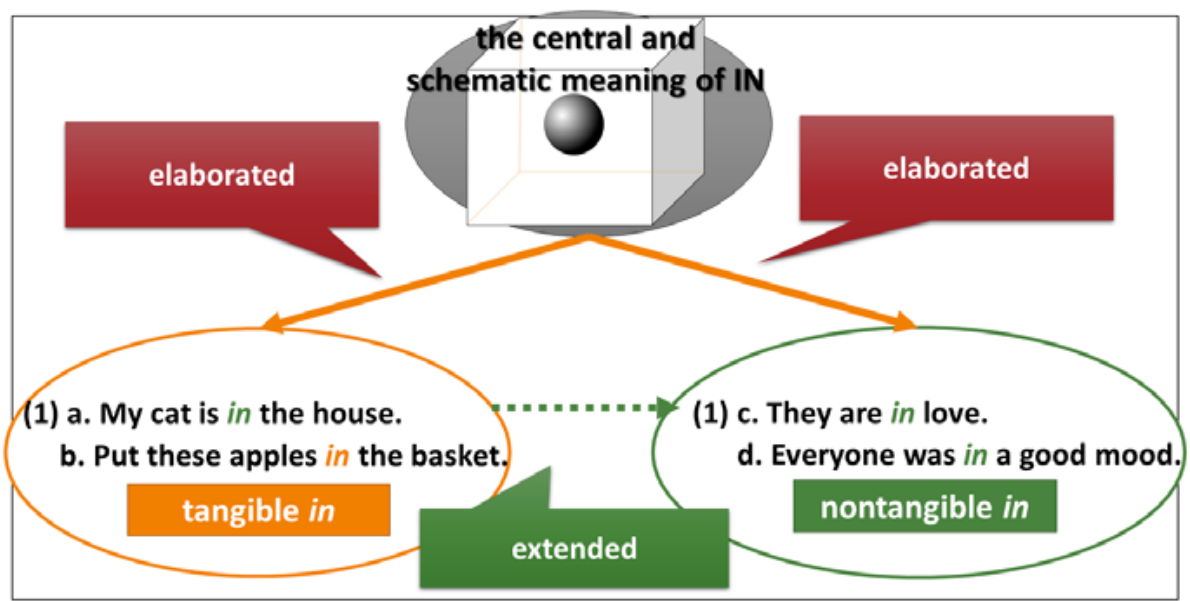

Figure 3. The central meaning of in and its elaborated examples.

The diagram in Figure 3 is one of the models proposed in cognitive linguistics to generally account for the phenomenon of meaning extension. For native English speakers, there is no difficulty in understanding that good mood and love can contain people as a house can contain a cat, but this is not the case for native Japanese-speaking students. Even though image schemas represent primordial and primitive kinesthetic patterns, not all are shared across languages. Image schemas are mental representations that are created, stored, and utilized within each language community.

In 2014, we administered a test to 111 Japanese-speaking 1st- and 2nd-year undergraduate students. We asked them to choose the correct preposition out of five (in, on, at, off, and out of) to complete sentences (see Appendix A). The questions were composed of two parts: choosing the correct prepositions to describe the relationship between tangible objects (e.g., "She was standing [ ] the snow"), and choosing the correct prepositions to describe the relationship between nontangible objects (e.g., "British agriculture is [ ] crisis"). The graph in Figure 4 indicates the proportion of errors with the preposition in. This shows that they understood the usage of the tangible in better than the nontangible in.

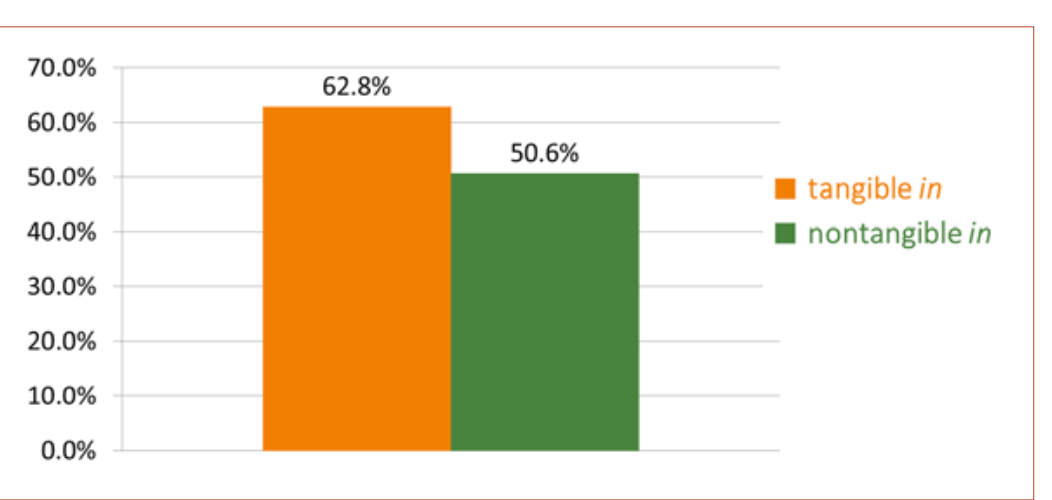

Figure 4. Correct answer rates of in on the test by Japanese university students. $N=111$.

The results in Figure 4 point out that some participants had not acquired the central or schematic meaning of in and its extensional use, the nontangible in. Given the data, the fact that the students did not know that the image schema can be carried over metaphorically to the abstract concepts, or that they did not acquire the image schema itself, directly caused errors.

The Shortcomings of Conventional Grammar Textbooks and the Advantages of the Image Schema-Based Method

The way prepositions are presented in conventional grammar textbooks suggests that students are not provided with ways of generalizing patterns. These textbooks do not generalize the patterns underlying all the usages of a preposition, and problems arise from a lack of integrated descriptions for every preposition. For example, the widely used grammar textbook written by Egawa (1991) demonstrates 12 meanings of the preposition in with verbal explanations (pp. 415-418). This suggests that learners are not supported in making generalizations of all of the various meanings of the preposition by themselves. On the other hand, as image schemas are schematized and integrated meanings of the lexical and grammatical concepts of a language, they may be a way for students to grasp the whole map of grammar items in a cohesive manner. Several studies have been made by other researchers to support the idea of using image schemas in grammar teaching. Kurtyka (2001) is perhaps one of the earliest studies that emphasized the significant role of image schemas in ESL. Even though he did not conduct any experiments, he was the first to stress, from a linguistic point of view, that visualization is 
an indispensable part of learning and that visual representations of meaning can provide a chance for learners to gain a better understanding of the semantics of prepositions and phrasal verbs. Taniguchi's (2011) investigation revealed the efficacy of showing image schemas in teaching the preposition up. After he showed the image schemas (including some variants) of $u p$ to his native Japanese-speaking students, they were able to correctly understand the meanings of unfamiliar idioms involving the word. Fujimori and Yoshimura (2013) also presented positive results in a similar experiment with Japanese-speaking students in which the experimental group who studied prepositions (over and above) with schematic visual animations received better scores on the posttest than the control group who studied the same prepositions with only the corresponding Japanese translations.

In 2014, we also conducted an experiment with the aforementioned 111 undergraduate students to measure the effectiveness of image schema-based explanations of five prepositions, in, on, at, off, and out of. The students were randomly divided into two groups. The experimental group studied the five prepositions with image schema-based explanations and the control group studied them with conventional verbal-based grammar textbooks, including Egawa's (1991) textbook. The experimental group $(n=$ $52)$ studied with image schema-based materials. The control group $(n=59)$ studied with conventional materials. Figure 5 and 6 show the correct answer rates of the two groups on the pretreatment and posttreatment tests.

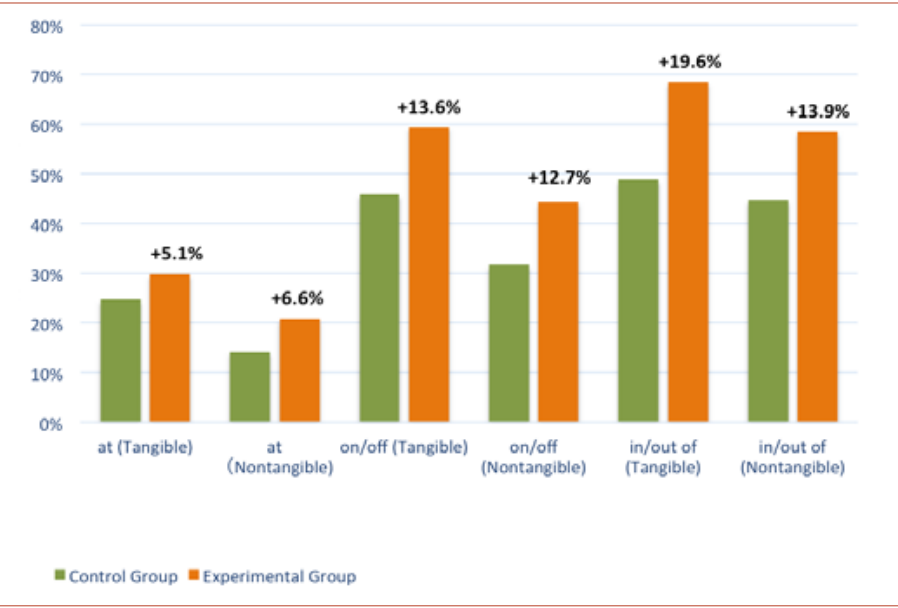

Figure 5. Correct answer rates on each set of prepositions on pretreatment test. $N=111$; "+ indicates the average percentage difference between the groups.

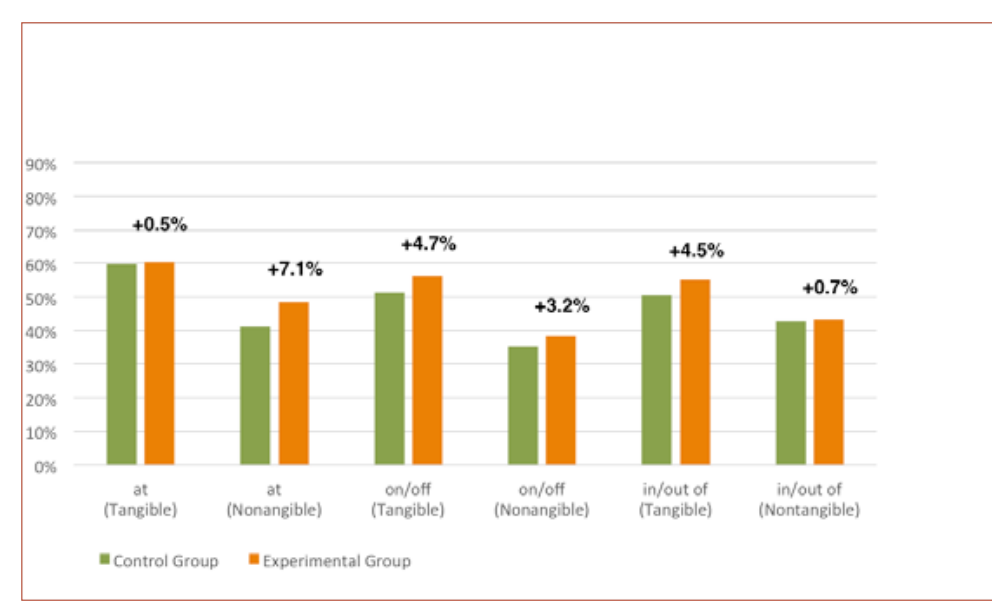

Figure 6. Correct answer rates on each set of prepositions in posttreatment test. $N=111$.

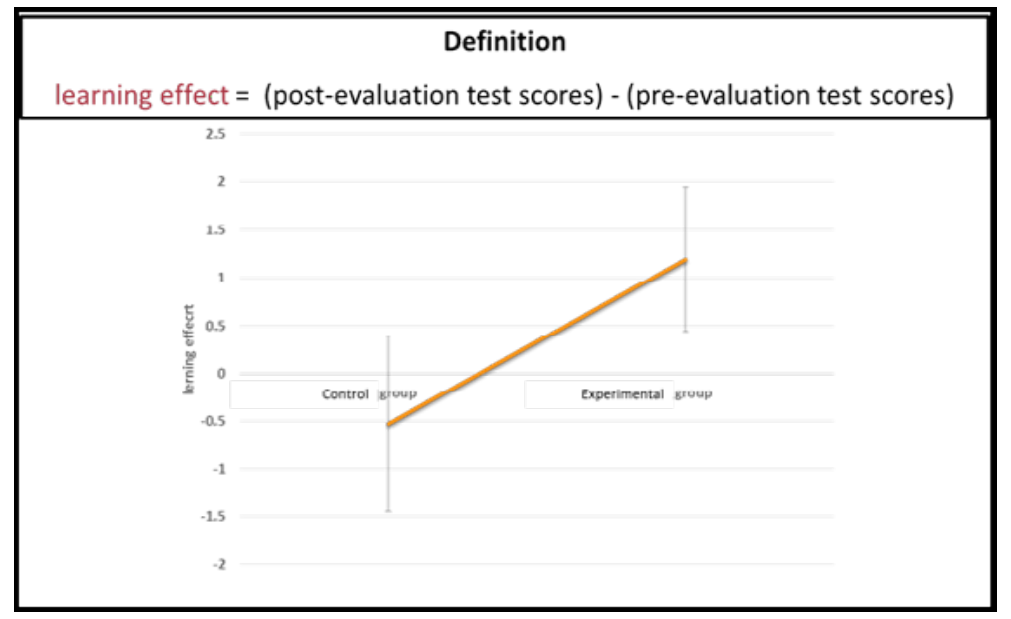

Figure 7. Significant difference in learning effect between the experimental group and the control group. 
We confirmed statistical significance between the experimental group and the control group $(t(109)=-2.78, p<0.01, d=0.53)$. Here, the greater the magnitude of $t$ (either positively or negatively) and the smaller the $p$ value (smaller than or equal to 0.05 ), the greater the evidence of a significant difference between the two groups. The $d$ value measures the meaningfulness of such a difference (greater than or equal to 0.3 means a noticeable effect). We concluded that the experimental group acquired the meaning of the prepositions more effectively than the control group. These results indicate that the grammar teaching approach coupled with the image schema theory may have provided students with a more integrated and organized way of understanding grammar in their second language. However, this investigation was limited to the teaching of prepositions (including phrasal verbs). Thus, our research question here is whether or not image schema theory can be applied to other grammar items. To explore this, we conducted an experiment on other grammar items with more than 400 native Japanese-speaking students in 2015.

\section{Research Questions}

Our research questions posed in this experiment were as follows:

RQ1. Does image schema-based instruction work with other grammar items?

RQ2. Is image schema-based instruction in English grammar more effective than conventional instruction?

RQ3. Is image schema-based instruction more comprehensible to students than conventional instruction?

In order to obtain answers to these three questions, we designed an experiment as outlined below.

\section{Methodology \\ Participants}

The experiment was conducted in 2015 with 424 1st- and 2nd-year undergraduate students from one national and one private university. We randomly divided the participants into two groups and found no significant differences between the two groups on the pretreatment test as shown in Figure 8. One group, consisting of 228 students, studied grammar with image schema-based materials (the IS group). The other group (the CV group), consisting of 196 students, studied the same grammar items with conventional materials. Figure 9 shows the demographics of the participants. Both the male vs. female and humanities vs. sciences ratios were well balanced.

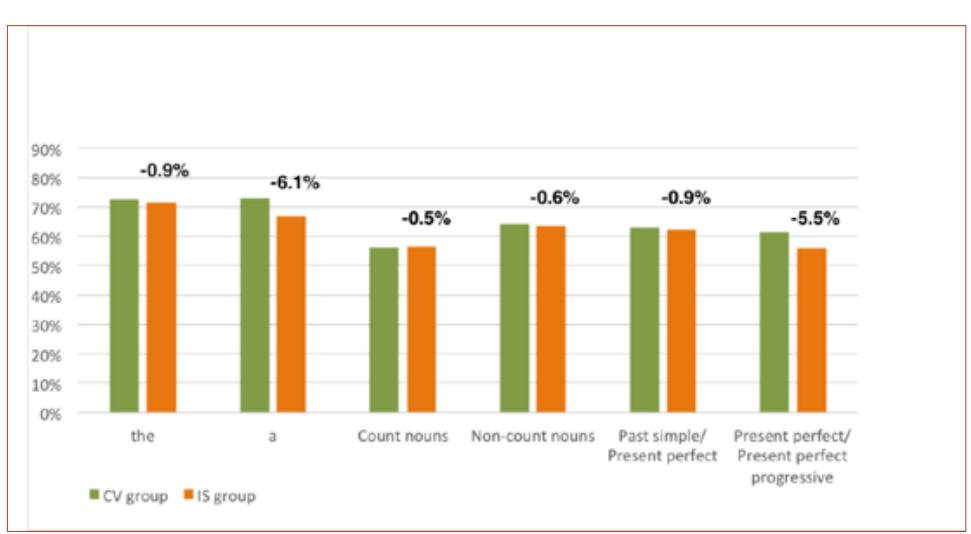

Figure 8. Correct answer rates on each grammar item on the pretreatment test.

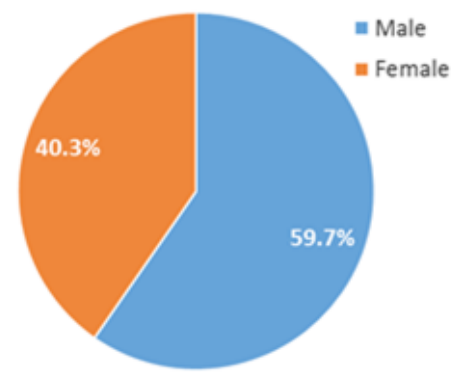

Figure 9. Participants by gender. $N=424$.

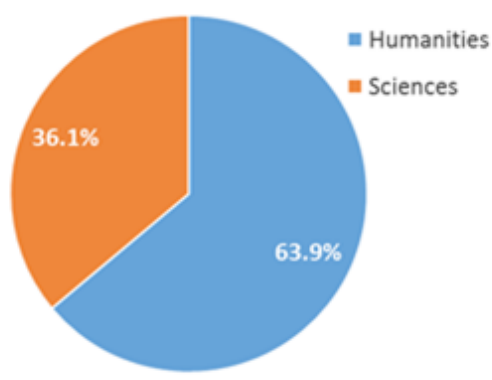

Figure 10. Participants by academic major. $N=424$. 


\section{Procedures}

\section{Grammar Items}

The explanations given to the participants were composed of three parts:

- 1: explanations on the difference between countable and noncountable nouns;

- 2: explanations on the difference between definite and indefinite articles; and

- 3: explanations on past tenses-the difference between past simple and present perfect and the difference between present perfect and present perfect progressive.

We selected these three grammar items because they are, in our experience, concepts with which Japanese-speaking students learning English generally feel uncomfortable. Indeed, the Japanese language does not differentiate between countable and noncountable nouns, or definite and indefinite information. The same is true of the past tense: many students do not understand the functional differences between past simple and present perfect or between present perfect and present perfect progressive.

\section{Study Time and Media Employed}

Each of the participants studied on a PC or tablet via an e-learning system for their convenience (and due to a lack of space needed to assemble participants at one time). The study time for the two groups was the same: 15 minutes for each grammar item.

\section{Two Tests and Method of Analysis}

Before and after the lessons, the participants took two different tests. The questions in the posttreatment test were different from those given on the pretreatment test (see Appendix A). Each test was composed of 33 questions about the selected grammar items. The questions were taken from several grammar and TOEIC textbooks. Finally, we used comparative $t$-test analysis to find the difference in learning effects between the two groups. We evaluated the learning effects by comparing the scores of the two groups in the posttreatment tests.

\section{Questionnaire}

After the posttreatment test, the two groups were asked to answer two questions:

1. How easy was it to understand the method? (Each group was asked about the method they followed.)
2. Do you have any comments on the learning method?

To the first question, participants responded using a 5-point Likert scale, with 1 meaning very comprehensible, and 5 meaning not at all comprehensible. For the second question, we asked the participants to write any comments or impressions they had about the learning method they had used.

\section{Teaching Materials}

The teaching materials used were as follows:

- The IS group studied three lessons about the selected grammar items with image schema-based explanations displayed in PowerPoint files.

- The CV group studied three lessons on the same items but with conventional verbal-based explanations in PDF files.

\section{Details of CV and IS Materials}

\section{Materials}

For the $\mathrm{CV}$ group, we assembled materials from conventional grammar textbooks recommended for university-level English learners (see Appendix B). The main problem with the $\mathrm{CV}$ materials was the lack of comprehensive descriptions of each grammar item. For example, Sugiyama (1998, pp. 239-240) aims to demonstrate the difference between past simple and present perfect by comparing two sentences (I have written a letter and I wrote a letter) with Japanese translations. He also gives the following explanation: "the decisive difference of past simple from present perfect is that the former expresses a detached and irrelevant action and state from the present time, whereas present perfect connects the action to the present time" (author's translation). In addition, the textbook seems to encourage learners to rely on the Japanese translation for each English example to get a better understanding of the functional differences between the past tenses.

\section{IS Materials}

In all IS lessons, we showed the participants the following three elements: the image schema of the targeted grammar item, several English examples as an instantiation of the image schema, and verbal explanations about the image schema. The IS materials utilized the animation system available on PowerPoint. All of the slides presented to the participants had moving image schemas as in Figure 11. 
(1)

I lost my key but I found it in the fridge

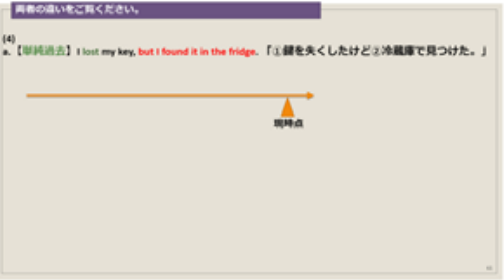

(2)

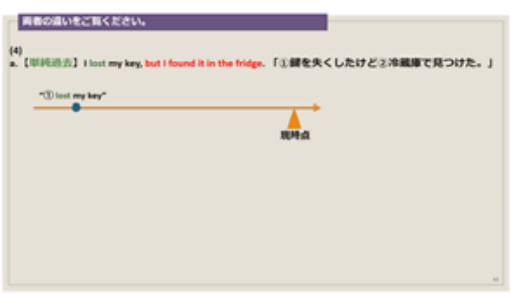

(3)

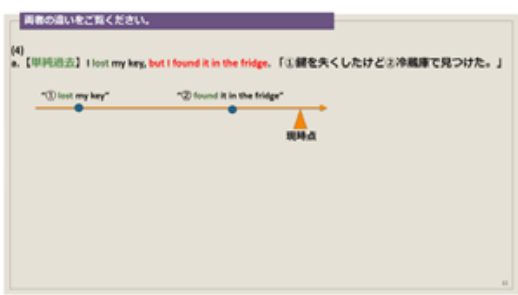

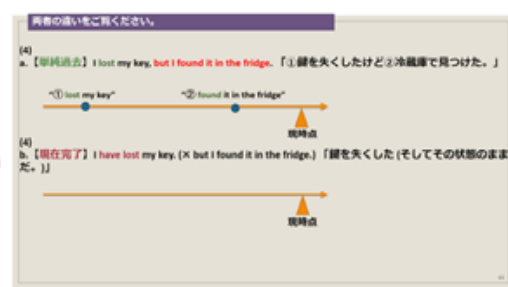

(2)

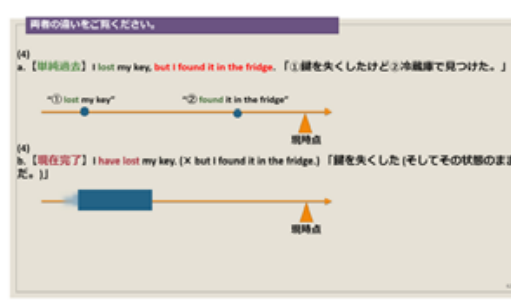

(3)

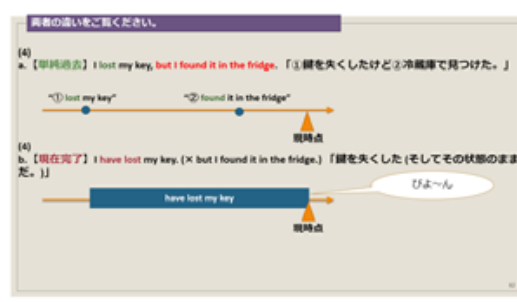

\section{I have lost my key}

Figure 11. Example of image schemas with animation.

Figure 12 displays a part of the lesson on countable and noncountable nouns. In the lesson, the participants viewed the image schemas of countable and noncountable nouns (the two circles with solid or dotted lines in the diagram) with appropriate sentences or phrases. A pair of clear pictures was also displayed one after another against the two-circle image schemas.

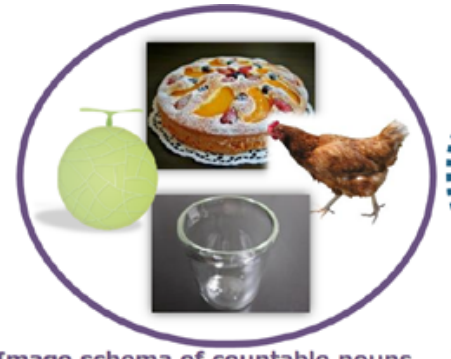

Image schema of countable nouns

I ate a melon.

There is a glass on the floor.

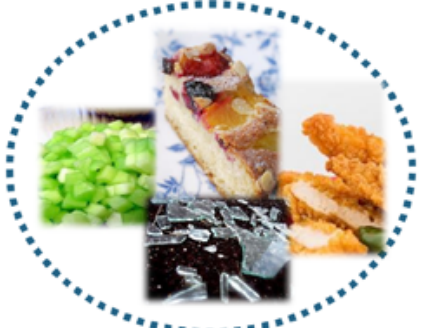

Image schema of non-countable nouns

\section{I ate melon.}

There is glass on the floor

Figure 12. Image schemas of countable and noncountable nouns and their instantiations.

Figure 13 displays part of the lesson on the difference between the definite and indefinite articles $a$ and the. The function of the indefinite article $a$ is to indicate that the given entity represents one of many. Nevertheless, for many students the meanings of $a$ country and the country seem to be identical. To explain this concept, we prepared a schematic image of $a$, as in Figure 13, where Japan is highlighted compared to the other countries. This helps the students see that there are other countries besides Japan surrounded by the sea.

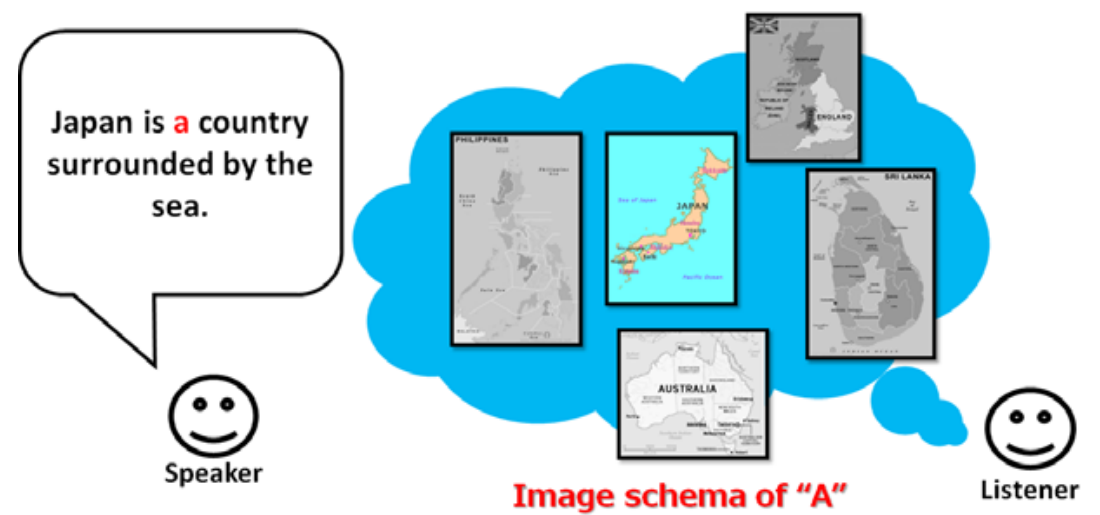

Figure 13. Image schemas of indefinite article $a$ and its elaborated example. 
Figure 14 describes the difference between past simple and present perfect with two image schemas. The participants saw the three past activities in past simple form described with dots that appeared one after another on the timeline. On the other hand, the two past activities in present perfect form carried over to the present. This dynamic explanation helped the participants see how the meanings of the two tenses are different.
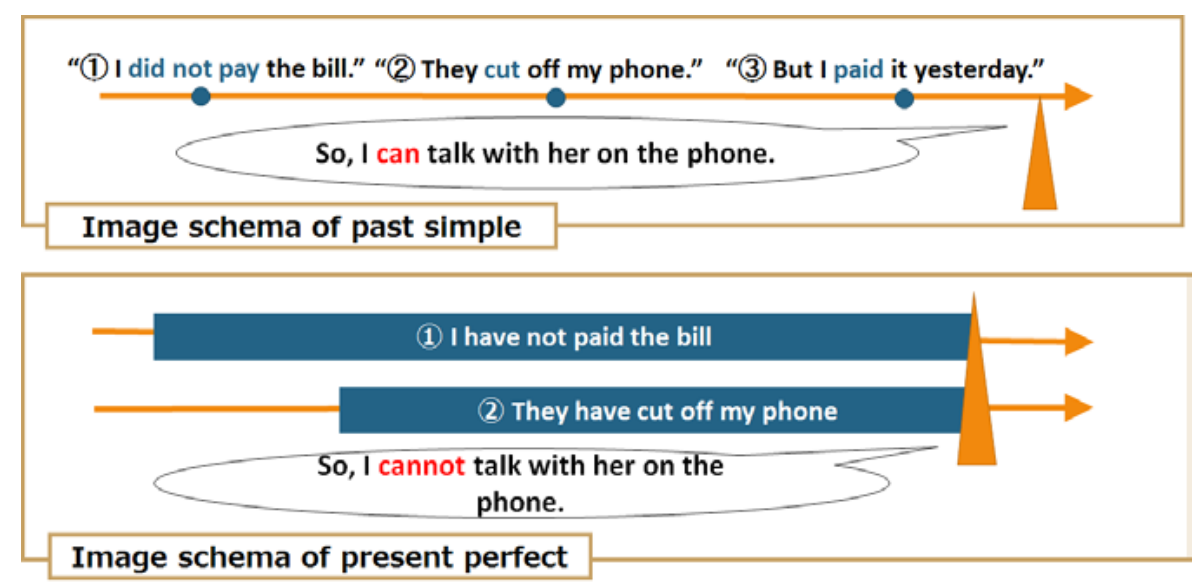

Figure 14. Image schemas of past simple and present perfect tenses.

The same idea was also employed to describe the difference between the present perfect and present perfect progressive tenses. In Figure 15, the activity in present perfect progressive carries over to the future, whereas the present perfect stops at the time of speech, so that the participants realize the difference between the tenses.

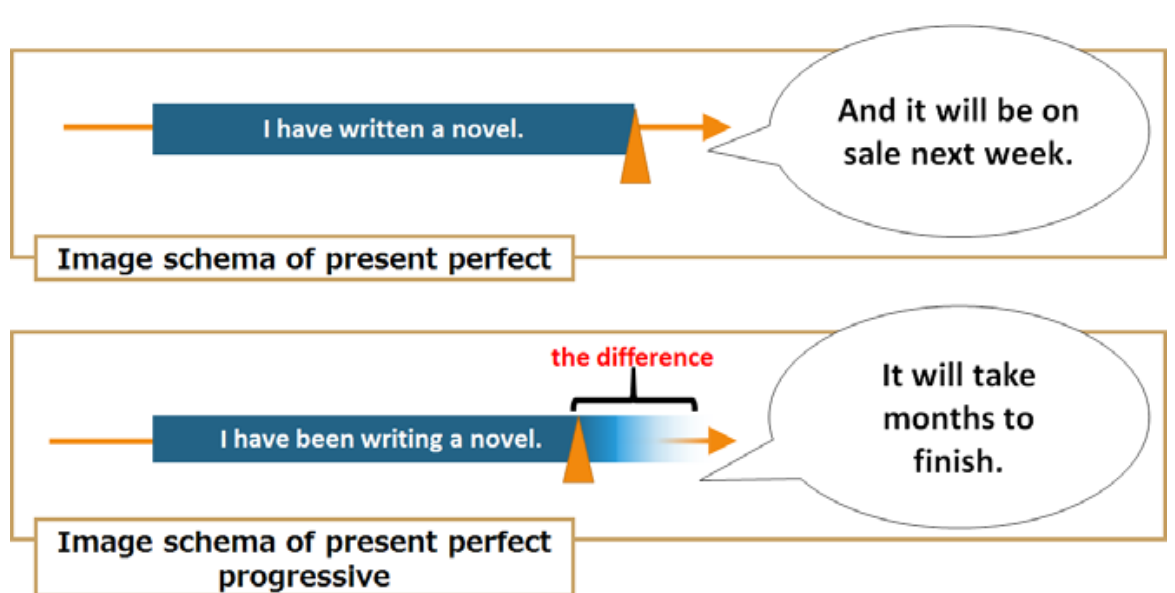

Figure 15. Image schemas of present perfect and present perfect progressive tenses.

Results

Correct Answer Rate for Each Grammar Item on the Posttreatment Test

Figure 16 illustrates the percentages of correct answers on the posttreatment test for each group by grammar item. The IS group's scores were higher than the CV group's, except for the definite article the.

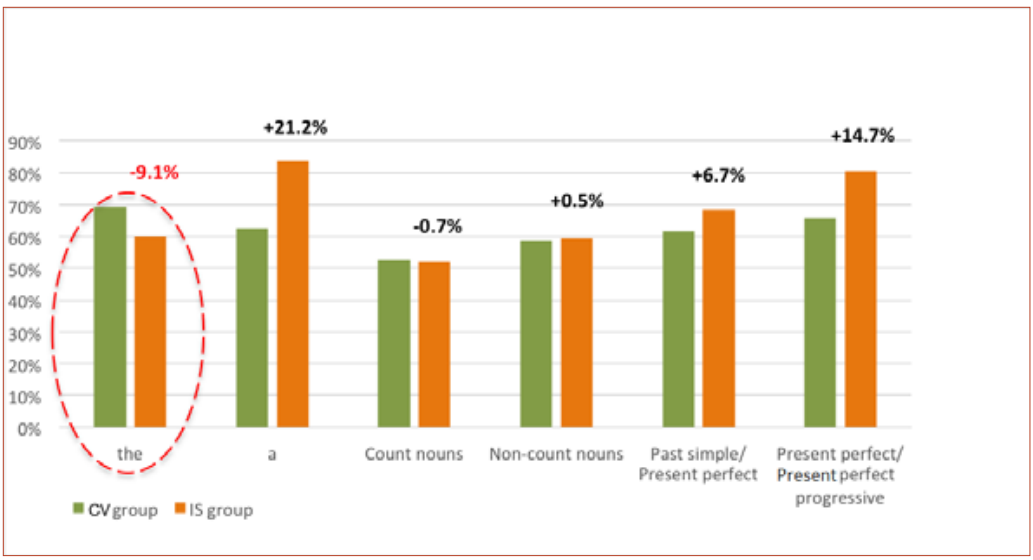

Figure 16. Correct answer rates on each grammar item on the posttreatment test. 


\section{General Learning Effect and Significant Difference Between the IS} and CV Groups

To measure the general effectiveness of the image schema-based teaching method, we used statistical testing to detect any difference in learning effect between the IS and CV groups. The graph in Figure 17 shows that the IS group experienced statistically significant advantages.

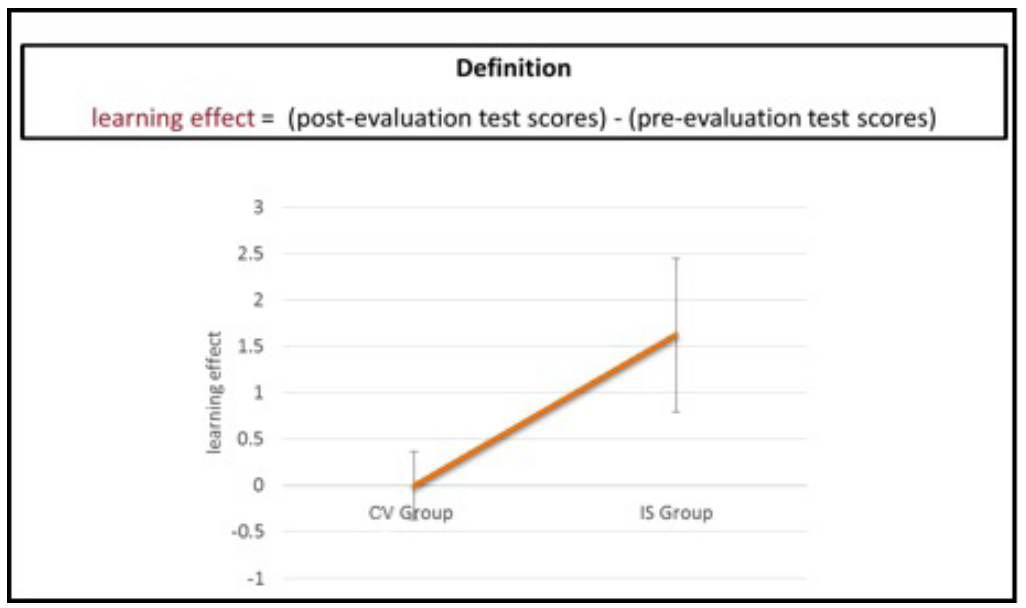

Figure 17. Significant difference in learning effect between IS and CV group.

The results showed the difference of learning effects: $t(346)=-3.35, p<-0.01, d=0.36$ ). Here, we use statistical testing where $t$ value and $p$ value measure the difference between the CV group and IS group. Thus, we can conclude that the image schema based instruction was more effective overall than conventional instruction.

\section{Comprehensibility of the Methods}

After the posttreatment test was completed, the participants were asked about their impressions of the instructional method they had used. Figure 18 shows the level of comprehensibility of each method according to the participants. Comparing the two bars, we see that the percentage of students who reported, "the method was very comprehensible" was $22.3 \%$ for the image schema-based method, while it was $8.1 \%$ for the conventional method. In total, $67 \%$ of the participants in the IS group had a positive impression of the method used, while only $46.9 \%$ of the participants in the CV group had a positive impression of the method used.

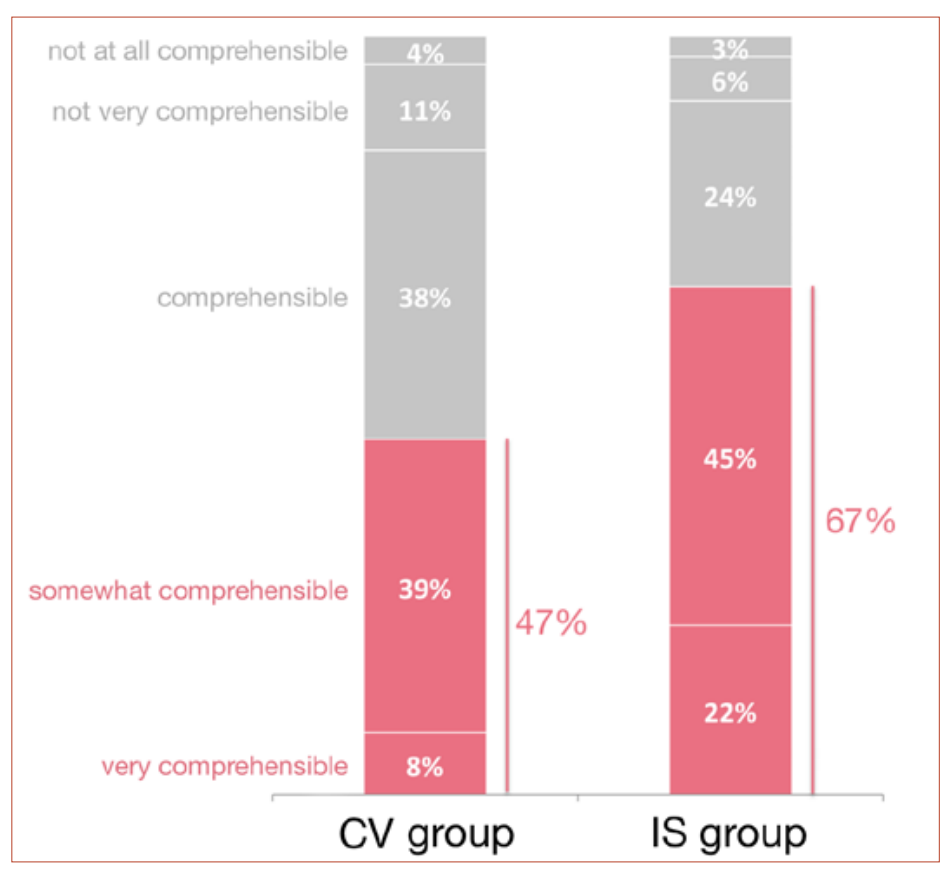

Figure 18. Participant assessment of comprehensibility of the methods.

\section{Discussion}

The goal of this study was, through the use of image schemas, to foster the students' understanding of English grammatical concepts that are absent in Japanese. Although we obtained confirmation by $t$-test analysis that overall the IS group demonstrated statistically significant advantages, the IS group scored lower than the $\mathrm{CV}$ group in choosing the correct usage of the definite article. From this result, it follows that the IS method was less successful at fostering the understanding of the definite article through the image schema used. There may be two possible reasons to account for this. First, it may have been due to the unbalanced exposure to the definite article image schema. In the definite and indefinite article lesson, the definite article image schema appeared two times, while the indefinite article image schema appeared four times. In other lessons, image schemas

\section{W FRONT PAGE}


for each concept appeared 5.5 times on average. (For example, the countable noun and noncountable noun image schemas both appeared six times, and the past simple image schema and the present perfect image schema appeared five and six times, respectively.) Second, the discrepancy may have been caused by the number of example sentences shown with the definite article image schema. In the lesson on the definite and indefinite articles, the number of example sentences presented in the CV material was approximately twice that of the IS material: eight sentences in the IS material, and 15 in the CV material. If we consider sentences to be instantiations of image schema, it is evident that image schemas for each grammatical concept should have been shown a sufficient and equal number of times for optimal student comprehension.

\section{Student Feedback on the IS Method}

Considering that $67 \%$ of the students felt the IS method was either very or somewhat comprehensible, it suffices to say that the IS method was positively accepted by the students in this study. There were also several students who wrote positive comments about the IS method. Some said the IS method stimulated their curiosity to learn more about grammar, and others said the animations were fun to watch because they gave the students a rhythmical process for understanding grammar.

\section{Conclusion}

In summary, we have drawn the following conclusions:

1. In this study, we developed a new educational method of English grammar teaching by applying the image schema theory that is supported by cognitive linguistics.

2. We confirmed the validity of the learning effect of our experimental method by using a $t$ test.

3. The participants who studied the function of the definite article with our new educational method did not score better than those who studied it with the conventional, verbal-based method. We suggested two possible reasons for this result.

4. The students who responded that they had a positive impression of our new educational method were $67 \%$.

The above results indicate the potential positive effects of supplementing traditional in-class verbal instruction and conventional, verbal-based materials with image schemas to support learners. For educators wishing to create their own visualized, image schema-based materials, this study can offer several suggestions. First, the image schema theory was developed through studies by Lakoff (1987) and Johnson (1987), and elaborated in Lakoff and Johnson (1999). These studies are highly theoretical, but useful for understanding the basics of image schema theory. Second, for practical purposes, Radden and Dirven (2007) is also worthy of study. Their textbook nicely introduces the notion of image schemas to university-level (English-speaking) students and offers a schematized way of analyzing grammar. Finally, Gibbs and Colston (2006) described the psychological reality of image schemas developed by infants.

To conclude, we provide two suggestions for further studies:

1. Further research is needed to improve the IS method on definite and indefinite articles and reorganize an experiment to examine their outcomes. Currently, we are planning to conduct another experiment with an online supplementary activity. In this experiment, the learners will receive image schema-based instructions on the target grammar items and practice these items orally with an English-speaking instructor.

2. A foreseeable extension of this research would be to include other languages, as every language has its own image schemas. Accordingly, image schema-based instruction should also assist learners of other languages.

\section{Acknowledgments}

Mori's participation in this project was supported by JSPS Grant-in-Aid for Young Scientists (B) Grant Number 26750075. We wish to thank the two reviewers for the time they spent reading our manuscript and their valuable comments and suggestions to improve this paper.

\section{Bio Data}

Mayu Shintani is a full-time instructor at Tokyo Denki University. Formerly, she taught English classes at the University of Tsukuba and linguistics at Kawamura Gakuen Woman's University. She received a PhD in linguistics from the University of Tsukuba in 2012 for a comparative and contrastive study of rhetorical expressions in English, French, and Japanese. She has also studied at the Graduate School of Literature, Culture and Social Sciences at the University of Caen Normandy in France. <mayu.j-s@mail.dendai.ac.jp>

Kazumasa Mori is an associate professor in the faculty of business administration at Bunkyo University. He received a PhD in multisciences from the University of Tokyo for educational measurement and related mathematical statistics. He engages in the evalua- 
tion of academic curriculums, focusing on the effects of newly organized English courses at the university, such as online English courses and debate courses. <morikzm@nifty. com>

Takuya Ohmori is a professor in the School of Management and Information Sciences at Tama University. His research domain is mainly related to educational engineering. $<$ ohmori@tama.ac.jp >

\section{References}

Egawa, T. (1991). Eibunpou kaisetsu [A new guide to English grammar] (3rd ed.). Tokyo: Kaneko-Shobo.

Evans, V. (2007). A glossary of cognitive linguistics. Edinburgh, Scotland: Edinburgh University Press. Fujimori, A., \& Yoshimura, N. (2013). Animated instructions for directional prepositions. CELES Journal, 42, 77-82.

Gibbs, R. W., Jr., \& Colston, H. (2006). The cognitive psychological reality of image schemas and their transformations. In D. Geerearts, (Ed.), Cognitive linguistics: Basic readings (pp. 239-268). New York, NY: Mouton de Gruyter.

Johnson, M. (1987). The body in the mind. Chicago, IL: The University of Chicago Press.

Johnson, M. (2005). The philosophical significance of image schemas. In H. Beate \& J. E. Grady (Eds.), From perception to meaning: Image schemas in cognitive linguistics (pp. 15-34). Berlin, Germany: Mouton de Gruyter.

Kurtyka, A. (2001). Teaching English phrasal verbs: A cognitive approach. In P. Martin, S. Niemeier, \& R. Dirven (Eds.), Applied cognitive linguistics 2: Language pedagogy (pp. 29-54). New York, NY: Mouton de Gruyter.

Lakoff, G. (1987). Women, fire, and dangerous things: What categories reveal about the mind. Chicago, IL: University of Chicago Press.

Lakoff, G., \& Johnson, M. (1999). Philosophy in the flesh. New York, NY: Basic Books.

Langacker, R. W. (2008). Cognitive grammar: A basic introduction. New York, NY: Oxford University Press.

Radden, G., \& Dirven, R. (2007). Cognitive English grammar. Amsterdam, The Netherlands: John Benjamins.

Taniguchi, K. (2011). Ouyou ninchi gengo gaku to goi gakushuu - bunpou riron o eigo kyouiku ni katsuyou suru (2) [Applied cognitive linguistics and the acquisition of vocabulary: Application of grammatical theories to English education (2)]. Memoirs of Osaka Kyoiku University, 59(2), 63-74. Retrieved from <http://ir.lib.osaka-kyoiku.ac.jp/dspace/handle/123456789/25446>

\section{Appendix A}

Samples of the Questions Used in the Tests in 2014

\section{Choose the correct answers from the given options.}

- The bomb exploded (on/off/in/out of/at/分からない) 300 meters.

- He couldn't play (on/off/in/out of/at/分からない) a high level with a sore back.

- He was chosen (on/off/in/out of/at/分からない) a hundred applicants.

- He paid for the camera (on/off/in/out of/at/分からない) his savings.

- He was standing (on/off/in/out of/at/分からない) the snow.

- British agriculture is (on/off/in/out of/at/分からない) crisis.

- She's carrying several bags (on/off/in/out of/at/分からない) her shoulders.

- I told them we were also going to talk (on/off/in/out of/at/分からない) health care.

- He was thrown (on/off/in/out of/at/分からない) the horse.

- I was trying to keep her mind (on/off/in/out of/at/分からない) Alain.

Samples of the Questions Used in the Pre- and Posttreatment Tests in 2015

\section{Choose the correct answers from the given options.}

Paris is (a/the/わからない) capital of France.

- It's a fine bicycle, but (brakes/the brakes/わからない) don't work.

- She was appointed as (a/the/わからない) chairperson of the committee.

- After breakfast the baby had (egg/ eggs/わからない) all over his face.

- We had an octopus for lunch. / We had octopus for lunch. / わからない

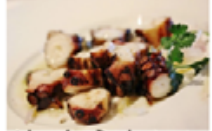

Mr. Bird (lived/has lived/わからない) on this street all his life. He still find it difficult to get along with his neighbors.

- Joan (broke/ has broken/わからない) the teapot, but it has been mended perfectly.

- I (have read/have been reading/わからない) your book, so I can return it to you. 


\section{Appendix B \\ Textbooks Used in Compiling CV Instruction Materials}

Egawa, T. (1991). Eibunpou kaisetsu [A new guide to English grammar] (3rd ed.). Tokyo: Kane-

ko-Shobo.

Sugiyama, C. (1998). Eibunhou shoukai [A comprehensive English grammar]. Tokyo: Gakken.

Yasui, M. (1996). Eibunhou souran [A better guide to English grammar] (2nd ed.). Tokyo: Kaitakusha. 